\title{
Study on the Integration of Information Technology and English Reading Teaching
}

\author{
Liu Liwen \\ NanChang Institute of Science \& Technology
}

\begin{abstract}
With the development of modern science and technology, information technology has been widely applied to education and teaching with more studies on the integration of information technology and subjects. However, during the implementation and practice, there have been also some setbacks in the early stage of integration since teachers paid more attention to information technology elements without realizing the purpose of applying information technology is to serve teaching. At present, the integration has become rational with increasingly more obvious advantages of information technology. Teaching of English reading class has always been an importance of teachers' teaching as well as a difficulty for students' learning. It is difficult to break through difficulties and important points by traditional teaching means and teaching methods. In this paper, the author elaborates that English reading teaching can get rid of the embarrassed situation with the help of information technology, and it can also break through the restriction of time and space, which can establish a more exciting and more vivid stage for teachers' teaching and students' learning.
\end{abstract}

Keywords-information technology; English; reading class; integration point

\section{INTRODUCTION}

Today's society is a society with rapid development, and the development of information technology has also brought opportunities for the rapid development of educational information technology. The future educational information is oriented by information technology. By far, the reform of new technologies in 21st century has affected directly and deeply on education. According to the development status of educational technology and trend of new technological reform, we find that the future educational information technology will give full play to its two key features by expanding development fields and developing application of technologies based on computers in education.

In the paper, the current situation of English reading class has been analyzed. First, the teaching concepts and teaching methods are backward; second, the formation of students' English reading ability can be affected by language factors; third, the development and improvement of students' English reading ability can also be impeded by non-language factors. Then an integration process of information technology and English reading class is displayed with an actual teaching case according to the characteristics of integration in different periods.

\section{II.PROBLEMS EXISTING IN THE INTEGRATION OF}

INFORMATION TECHNOLOGY AND ENGLISH READING

\section{CLASS}

Generally there are two problems existing in the integration of information technology and English reading class

\section{A. Problems of integration between information technology and subjects}

Information technology has been applied to the teaching of various subjects. Every night, our teachers manage to collect various teaching resources and delicately design various sections with sufficient preparation; however, the real purpose of information technology can't be reached since teachers have become the salves of mouses. We thought through information technology teachers can be closely connected to students, but they just turn from blackboard to PowerPoint. As the teaching contents are all prepared in advance, any problem occurs in class may make the teacher worried. 
learn new knowledge, but also their ability of integrating and flexibly applying knowledge can be cultivated.

\section{Study on the integration after reading class}

The after-school homework after the integration of information technology and reading class can be colorful. With passage teaching in class alone, students can't form good reading habit and obtain strong reading ability successfully. Therefore, after-class reading has become an effective supplement of class reading. Thus, students in higher grades are encouraged to read after-class English journals and books; and meanwhile they can read books on the Internet which can enlarge their input of English information with broad genres, original contents, diversified forms as well as colorful cultural knowledge.

\section{V.CONCLUSION}

Based on Integration of English reading under information technology environment as well as its supporting resources, the paper first studies and analyzes related theories of constructive study and new curriculum standards of English study; and then it elaborates the integration of English reading class and information technology for three steps, which are preview of reading class, integration in class and integration after class, during which the in-class integration is further divided into three steps according to the different functions of information technology. Through the display of integration case as well as elaboration of teaching methods in different stages, we thought that the integration of information technology and English reading class will surely bring great changes to both students' learning and teachers' teaching. According to my point of view, the deep development of this integration should rely on deep studies of English reading in different stages so as to discover teaching modes suitable for different stages as well as integration and countermeasures of different teaching circumstances.

\section{REFERENCES}

[1] Association, Japanese Gastric Cancer. "Japanese classification of gastric carcinoma: 3rd English edition." Gastric Cancer 14.2(2011):101-112.

[2] Martin, James R. "English Text: System and Structure." Loan/open Shelves (1992).

[3] Martin, J. R, and P. R. R. White. "The Language of Evaluation Appraisal in English." Schools \& Disciplines 23.2( mbert, Janet Breckenridge. "The phonology and phonetics of 2005):371-381.

[4] Pierrehu English intonation." Massachusetts Institute of Technology (2009).

[5] HORNSTEIN, NORBERT. Events in the Semantics of English A Study in Subatomic Semantics[J]. Mind \& Language, 1990, 8(3):442-449.

[6] Shannon, and E. C. "Prediction and entropy of printed English." Bell System Technical Journal 30.1(1951):50 - 64.

[7] Montague, Richard. "The proper treatment of quantification in ordinary English." Studies in Cognitive Systems 2(1973):141-162.

[8] Hornby, A. S., Wehmeier, S., Mcintosh, C., Turnbull, J., \& Ashby, M. (2005). Oxford advanced learner's dictionary of current English. Oxford University Press.

[9] Hughes, H. G. A. (2003). The cambridge grammar of the english language. Modern Language Review, 87(6), 127-141.

[10] Simpson, John. "The Oxford English dictionary." Mountain Bike Magazines 55.1(1989):1-3.

[11] Johnson, Jacqueline S, and E. L. Newport. "Critical period effects in second language learning: the influence of maturational state on the acquisition of English as a second language.." Cognitive Psychology 21.1(1989):60-99.

[12] Sejnowski, T. J., and C. R. Rosenberg. "“Parallel Networks That Learn to Pronounce English Text"." Complex Systems 1(1987). 